УДК: 331.101 .2

JEI: M 120

\title{
СУЧАСНІ ФОРМИ І МЕТОДИ МОТИВАЦІЇ ПЕРСОНАЛУ ПІДПРИЕМСТВ СФЕРИ ПОСЛУГ
}

\author{
Ірина Черниш*, доктор економічних наук, професор \\ Міла Козик**, PhD студентка \\ Національний університет «Полтавська політехніка імені Юрія Кондратюка»
}

ORCID* 0000-0001-6565-5292

ORCID** 0000-0002-7510-8839

\author{
(C) Черниш I., 2021 \\ (C) Козик M., 2021
}

Стаття отримана редакиією 18.03.2021 p.

The article received by the reduction 18.03.2021.

Вступ. Бажання і готовність персоналу виконувати свою роботу є одним із значущих чинників забезпечення ефективності діяльності підприємства. Вирішальною причиною результативності персоналу вважається їх мотивація, яка, на наш погляд, є системою внутрішніх і зовнішніх мотивів, які змушують працівника діяти певним чином. Мотивація персоналу передбачає довгостроковий вплив на працівника по заданих параметрах для зміни структури його ціннісної орієнтації та інтересів, формування мотиваційного ядра i розвитку на даній основі трудового потенціалу.

Огляд останніх джерел досліджень і публікацій. Проблема створення і впровадження сучасних методів мотивації персоналу в організації за останні роки набрала велику кількість суперечок. Одні автори трактують його як прогресивне, позитивне нововведення, яке раніше не застосовувалося в організації (І. Афонін, Л.М. Гохберг, В.Н. Гунин, П. Друкер, Ф. Ніксон, В.Устинова та ін.). Інші автори під «сучасними методами мотивації» розуміють результат творчої діяльності працівників, який призводить до змін в організаційній системі, $\mathrm{i}$, як наслідок, до появи комерційної вигоди від них (М.В. Кларін, В.М. Матіашвілі, М.Ю. Морозова, Г.А. Мотін, А.І.Пригожин, В.Г. Різдвяний і ін.).

Мета статті полягає у дослідженні основних форм і методів мотивації персоналу підприємств сфери послуг. Проаналізувати теорії мотивації персоналу з точки зору їх застосування на практиці, розглянути групи методів мотивації та дати оцінку їх ефективності.

Основний матеріал. Сучасні організації сфери послуг працюють в умовах дуже жорсткої конкуренції, що змушує керівництво шукати найбільш ефективні методи роботи. У той же час, головною конкурентною перевагою організацій сфери послуг $є$ їх персонал. Тому особливо актуальною $є$ проблема побудови ефективної системи мотивації працівників. А. Файоль, виділяючи функції управління персоналом, позначив в числі пріоритетних мотивацію.

Мотивація - це стимули, які спонукають людину виконувати певну дію. Таке розуміння лежить в основі різних мотиваційних систем, що застосовуються в бізнесі і стимулюючих персонал до збільшення результативності праці і зниження витрат фірми. В даний час існує більше 300 теорій мотивації. На наш погляд, стосовно аналізованої сфері, найбільш повно і точно відображають фактори мотивації змістовні теорії, в числі яких піраміда потреб А. Маслоу, модель Ф. Герцберга, а також теорії «Х», «У», «Z», що пояснюють мотивацію працівників з точки зору людських ресурсів (табл. 1).

Немає єдиного правила або способу мотивації персоналу, але існують принципи розробки власного ефективного методу:

1. Дієвою буде мотивація, що дозволяє службовцю відчути себе важливим і потрібним. Таке заохочення викликає повагу і добру заздрість серед колег. Однак у всьому слід знати міру, в іншому випадку втрата нагород призведе до моральної дискваліфікації працівника.

2. Непередбачені одноразові заохочення працюють успішніше системних (щомісячне нарахування премії за якісну роботу). До системних методів швидко звикають і вважають їх частиною норми. 
3. Похвала діє краще покарання.

4. Реакція керівництва (позитивна чи негативна) повинна бути негайною. Таким чином, підлеглий відчуває себе значущим: начальнику небайдужі його досягнення або промахи.

5. Проміжний результат це теж результат! Стимулювання працівників за маленькі успіхи дозволить прискорити досягнення головної мети [3].

Таблиця 1

Зміст теорій мотивації персоналу [1]

\begin{tabular}{|l|l|}
\hline \multicolumn{1}{|c|}{ Теорія мотивації } & \multicolumn{1}{|c|}{ Зміст теорії мотивації } \\
\hline Піраміда потреб А. Маслоу & $\begin{array}{l}\text { Людина задовольняє потреби за ступенем їх значимості: від більш } \\
\text { насущних до менш. Розвиток особистості можливе за умови, що } \\
\text { людина задовольнивши нижчі потреби (вітальні, потреба в безпеці), } \\
\text { може задовольнити потреби більш високого порядку (в приналежності, } \\
\text { у повазі, в самоактуалізації) }\end{array}$ \\
\hline $\begin{array}{l}\text { Двухфакторна модель } \\
\text { Ф. Герцберга }\end{array}$ & $\begin{array}{l}\text { Всі фактори, що визначають ефективність працівника і мотивують } \\
\text { його до праці, розділені на внутрішні і зовнішні. Внутрішні чинники } \\
\text { визначають задоволеність працею: професійний успіх, перспективи } \\
\text { зростання і розвитку, визнання професійних досягнень і зовнішні: } \\
\text { умови і зміст праці, умови оплати праці, відносини в колективі } 3 \\
\text { колегами і начальстом }\end{array}$ \\
\hline Теорія «Х» Д. МакГрегора & $\begin{array}{l}\text { Головним фактором є матеріальна залежність працівників. Тому, щоб } \\
\text { працівники найкращим чином виконували свою роботу, необхідно іх } \\
\text { симулювати в грошовій формі }\end{array}$ \\
\hline Теорія «У» & $\begin{array}{l}\text { Всі працівники мають певний потенціал, тому найкращих результатів } \\
\text { можна досягти, якщо створити умови для реалізації цього потенціалу. } \\
\text { Стимулами до праці є: самоствердження, моральне і матеріальне } \\
\text { заохочення, примус }\end{array}$ \\
\hline Теорія «Z» У. Оучі & $\begin{array}{l}\text { Співробітники, впевнені в завтрашньому дні, у своєму добробуті, } \\
\text { більш лояльні до організації і готові працювати з більшою віддачою }\end{array}$ \\
\hline
\end{tabular}

Незважаючи на існування переліку розроблених і прекрасно зарекомендували себе схем мотивації персоналу, багато керівників підприємств стикаються з деякими труднощами. Сучасному керівнику потрібно компетентно підійти до питання стимулювання підлеглих, щоб з найменшими витратами досягти високих показників функціонування організації. Система мотивації повинна відповідати основним потребам колективу і легко модернізуватися слідом за мінливими умовами.

Особливу увагу варто приділити виділенню грошових сум на корпоративні свята. Проведення подібних заходів допомагає згуртувати колег, прищепити персоналу корпоративний дух, налагодити дружні відносини між співробітниками [6].

Видів нематеріальної мотивації набагато більше. До них відносяться наступні.

Похвала від адміністрації організації. Якщо керівник зауважує не лише промахи підлеглих, а й успішно виконану роботу, не скупиться на похвалу, службовці прагнуть і надалі не розчаровувати керівництво. Тому в установах і сьогодні використовуються дошки пошани як форма заохочення добросовісних працівників [1].

Підвищення по службі. Кожен підлеглий знає, що за якісне виконання трудових обов'язків йому гарантоване підвищення на посаді. Це підвищує його статус серед колег і сприяє кар'єрному росту. Однак слід знати міру, в іншому випадку це призведе до конкурентної боротьби всередині колективу, і про командну роботу доведеться забути.

Підвищення кваліфікації за рахунок організації. Навчання підвищить професійний рівень персоналу і стане прекрасним способом мотивації працювати краще для кожного співробітника.

Створення дружньої, теплої атмосфери. Відсутність згуртованості у колег негативно впливає на роботу організації в цілому, в той час як дружна команда 3 легкістю впорається з найскладнішими питаннями.

Створення іміджу фірми і турбота про нього. Організація, яка завоювала популярність на ринку, приваблює не тільки потенційних клієнтів, але і робить престижної роботу в ній. А значить, це є чудовою мотивацією [5].

Організація спільного дозвілля. Робота в команді - це не тільки спільна праця, а й відпочинок. Виїзди на природу, спортивні змагання, спільне відвідування театру, музею, виставки здатні 
згуртувати весь колектив, а кожен співробітник буде дорожити своїм робочим місцем. Така мотивація персоналу заснована на принципі: хто добре відпочиває, той добре працює.

Наявність зворотного зв'язку - прекрасна мотивація службовців. Якщо кожен підлеглий знає, що його думка небайдуже керівництву, і не боїться пропонувати ідеї модернізації роботи, це позитивно позначається на всьому підприємстві.

Способи мотивації персоналу розробляються з певною метою: для стимулювання підвищення якості роботи підлеглих. Існує багато інноваційних методів підвищення працездатності. Всі їх умовно можна розділити на три основні категорії:

- Індивідуальна мотивація, яка має на меті роботу з окремими підлеглими [10];

- Моральна і психологічна мотивація - використовується для задоволення основних внутрішніх потреб працівників; установи.

- Організаційна мотивація - допомагає створити систему стимулів для службовців всередині

Загалом, опрацьовуючи значну кількість теоретичного та практичного матеріалу та досліджень, варто зауважити, що реалізація індивідуальних методів мотивації персоналу можлива в таких формах:

- Спільні святкування значущих подій в житті колег;

- Почергове призначення відповідального за організацію неформальних чи то корпоративних заходів;

- Оформлення кабінетів психологічного розвантаження та відпочинку персоналу;

- Інформування колективу про особисті досягнення кожного працівника;

- Проведення змагань [6].

Моральні та психологічні методики сприяють професійному розвитку службовця i підвищенню його працездатності. До них відносять:

1. Соціальне діагностування персоналу компанії. Діагностика допомагає встановити базові соціальні проблеми трудящих, вирішуючи які можна впливати на персонал.

2. Проведення тренінгів і змагань, спрямованих на виявлення людей з лідерськими якостями.

3. Створення особливої атмосфери. Сюди відносяться колірна гамма оформлення кабінетів, музика в приміщеннях для релаксу і можливість прояву творчості в повсякденній роботі.

В якості морального заохочення застосовують:

- похвалу працівника у присутності колег;

- особисту подяку керівника, висловлену усно або оформлену у вигляді листа [2].

Організаційні методи мотивації дозволяють систематизувати роботу установи і до них можемо віднести:

1. Організація нарад і планерок для всього колективу. Інформування підлеглих про завдання компанії, можливість почути думку кожного сприяють залученню в процес досягнення спільної мети всіх працівників.

2. Адміністрування. Включає в себе:

- оформлення переліку функціональних обов'язків підлеглих;

- вивчення нормативної бази, пов'язаної з функціонуванням установи;

- створення кодексу етики працівника компанії;

- культуру спілкування з клієнтами та колегами;

- формування системи заохочень і покарань, яка поширюється на весь персонал фірми.

Такі методики популярні в установах, де більшість службовців доводиться змушувати працювати, а керівництво налаштоване на застосування «батога і пряника». 3 іншого боку, чітке знання своїх обов'язків, а також наслідків їх невиконання - це важлива складова роботи кожного підприємства [4].

Грейдерування - одна з сучасних методик підвищення працездатності персоналу. Зазначений метод мотивації персоналу дозволяє сформувати ієрархічну «сходи» співробітників щодо їх цінності для компанії, на підставі якої розраховується система винагороди роботи кожного службовця. Критерії оцінювання, що застосовуються в грейдування: кваліфікація, освіта, відповідальність, старанність, продуктивність.

Серед усіх методів мотивації персоналу найбільш результативними є нестандартні. Такі методики не вимагають великих фінансових витрат і засновані на креативному підході керівництва 
до організації праці. Багато керівників заохочують кадрових службовців, що пропонують нестандартні підходи мотивування персоналу.

Прикладом таких нестандартних рішень $є$ :

- Жартівлива форма покарання недбайливих підлеглих. Не обов'язково знімати премію або штрафувати недбайливого працівника. Досить привласнити йому жартівливе звання «лінивця відділу»або «Черепахи місяці». Такі «титули» мотивують людини на підвищення якості своєї праці.

- Ігрові кабінети. Така методика надання приміщень, де можна пограти і відволіктися від рутинної роботи, відмінно зарекомендувала себе в багатьох іноземних компаніях. Така розвантаження підвищує працездатність колективу і покращує офісну атмосферу.

- Раптові подарунки. Несподіване заохочення (навіть незначне) мотивує працівника продовжувати працювати так само, а то і краще.

- Турбота про сім'ї. Це можуть бути новорічні ранки або подарунки для дітей, а також знижки для відпочинку членів сім'ї співробітників.

- Додатковий відпочинок. Не обов'язково виплачувати працівникам грошові премії. Додатковий вихідний - це відмінна альтернатива грошової винагороди.

- «Повторення», або методика аналогії. З'явилася вона під час кризи, коли багато фірм не мали можливості матеріально заохочувати своїх службовців. Заснована методика на психологічні особливості людей, а саме несвідомому наслідуванні. Начальник своїм прикладом мотивує підлеглих на якісне виконання професійних обов'язків.

Приємним додатковим стимулом може стати нагородження «працівників місяці» квитком в кіно або абонементом для відвідування басейну

Висновок. Різноманіття існуючих методів управління персоналом велике, проте, найбільшу ефективність використання методів принесе тільки в застосуванні їх в комплексі, а не окремо. Таким чином, при постійному вдосконаленні менеджменту персоналу на виході колектив отримує повне задоволення своїх потреб, а підприємство - реалізацію власних, і отримання прибутку.

Таким чином, вивчення проблем мотивації працівників і розробка інноваційних методів стимулювання і спонукання персоналу до більш ефективної трудової діяльності $є$ зараз одним 3 ключових умов успішного розвитку компанії і збереження гідного рівня конкурентоспроможності на ринку.

\section{СПИСОК ВИКОРИСТАНОЇ ЛІТЕРАТУРИ:}

1. Бала В.В., Мацак В.В. (2016). Процес мотивації персоналу підприємства та його складові. Технологический аудит и резервы производства. Харків, Україна. 3(3). 46-50.

2. Долішній I.М., Колодійчук А.В.(2017). Мотивація персоналу як об'єкт управління на підприємстві. Науковий вісник НЛТУ України. (20.5.). 211-216.

3. Колот А.М.(2017) Мотивація персоналу. К.: КНЕУ. 337.

4. Маринич І.А. (2018) Мотивація як фактор підвищення ефективності праці працівників. Науковий вісник НЛТУ України. (15.5). 376-380.

5. Капустянський П.3. (2017) Мотивація праці персоналу сучасних організацій (організаційно-управлінський аспект) [монографія]. К.: ІПК ДСЗУ. 155 с.

6. Мочерний С.В.(2010) Економічний словник - довідник. - К.: Феміна. 368 с.

7. Alge B.J., Anthony E.A., Rees J., Kannan K. (2010). Controlling A whilehoping for B: deviance deterrence and public versus private deviance. In The Dark Side of Management, ed. by L. Neider, C. Schriesheim, pp.115-41. Charlotte, NC: Inf. Age Publ.

8. Coovert M.D., Thompson L.F. (2014b). Toward a synergistic relationship between psychology and technology See Coovert \& Thompson 2014a, pp. 1-17.

9. DeSanctis G., Poole M.S. (1994). Capturing the complexity in advanced technology use, adaptive structuration theory. Organ. Sei. S (2): 121-47.

10.Goffman E. (1983). The interaction order. Am. Sociol. Rev. 48: 1-17.

\section{REFERENCES:}

1. Bala V.V., Matsak V.V. (2016). Protses motyvatsii personalu pidpryiemstva ta joho skladovi. Tekhnologicheskij audit i rezervy proizvodstva. Kharkiv, Ukraine, Vol. 3(3), pp. 46-50

2. Dolishnij I.M., Kolodijchuk A.V.(2017). Motyvatsiia personalu iak ob'iekt upravlinnia na pidpryiemstvi. Naukovyj visnyk NLTU Ukrainy, Vol. 20.5, pp. 211-216..

3. Kolot A.M.(2017). Motyvatsiia personalu. KNEU. Kiev. 337. 
4. Marynych I.A. (2018). Motyvatsiia iak faktor pidvyschennia efektyvnosti pratsi pratsivnykiv. Naukovyj visnyk NLTU Ukrainy. Vol. 15.5, pp. 376-380.

5. Kapustians'kyj P.Z. (2017). Motyvatsiia pratsi personalu suchasnykh orhanizatsij (orhanizatsijnoupravlins'kyj aspekt) [monograph]. IPK DSZU. Kyiv. 155 p.

6. Mochernyj S.V. (2010). Ekonomichnyj slovnyk - dovidnyk. Femina. Kyiv. 368 p.

7. Alge B.J., Anthony E.A., Rees J., Kannan K. (2010). Controlling A whilehoping for B: deviance deterrence and public versus private deviance. In The Dark Side of Management, ed. by L. Neider, C. Schriesheim, pp.115-41. Charlotte, NC: Inf. Age Publ.

8. Coovert M.D., Thompson L.F. (2014b). Toward a synergistic relationship between psychology and technology See Coovert \& Thompson 2014a, pp. 1-17

9. DeSanctis G., Poole M.S. (1994). Capturing the complexity in advanced technology use,adaptive structuration theory. Organ. Sei. S (2): 121-47

10. Goffman E. (1983). The interaction order. Am. Sociol. Rev. No 48, pp.1-17.

УДК: 331.101 .2

JEI: M 120

Черниш Ірина Володимирівна, доктор економічних наук, професор. Козик Міла Вікторівна, аспірантка. Національний університет «Полтавська політехніка імені Юрія Кондратюка». Сучасні форми і методи мотивації персоналу підприсмств сфери послуг. Мета статті полягає у дослідженні основних форм i методів мотивації персоналу підприємств сфери послуг. Проаналізовано теорії мотивації персоналу з точки зору їх застосування на практиці, розглянуто групи методів мотивації та дано оцінку їхній ефективності. Визначено, що для ефективності роботи персоналу на підприємстві необхідно індивідуально підходити до кожного працівника. Сукупність заохочень, які можна і потрібно застосовувати, щоб стимулювати працівника до якісного виконання своїх посадових обов'язків, називається мотивацією персоналу. Така мотивація починається з підбору висококласних фахівців на посаду й підтримується під час роботи керівником. Успішні фірми вкладають значний капітал у розвиток трудових ресурсів, розглядаючи його не як витрати, а як активи підприємства. Згодом капітал, вкладений в людей, зростає, а не зменшується, як капітал, вкладений в засоби виробництва. Саме людський капітал, а не заводи, устаткування й виробничі запаси забезпечують конкурентоспроможність та економічне зростання підприємства. Управління персоналом включає багато складових. Серед них: кадрова політика, взаємовідносини в колективі, соціально-психологічні аспекти управління. Ключове ж місце займає визначення способів стимулювання i мотивації працівників. Мотивація $\epsilon$ одним 3 найважливіших внутрішньоорганізаційних процесів, а особливість його полягає в тому, що він безпосередньо спрямований на досягнення цілей організації. Успіх підприємства є результатом взаємодії між співробітниками і клієнтами, продуктом і організацією. Тому, щоб створити клієнтоорієнтовану компанію, ці три елементи мають працювати разом задля отримання прибутку організації та фінансових вигід для співробітників. Це може бути досягнуто шляхом надання винагород та стимулів або вигод в обмін на їх ефективну роботу для досягнення цілей організації.

Ключові слова: персонал, мотивація, сфера послуг, методи мотивації, форми мотивації.

UDC 331.101.2

JEI: M 120

Chernysh Iryna, Doctor of Sciences (Economics), Professor. Mila Kozyk, PhD Student. National University "Yuri Kondratyuk Poltava Polytechnic». Modern Forms and Methods of Employees Motivation at Service Companies. The purpose of the article is to study the main forms and methods of motivating staff of enterprises in the service sector. The authors analyzed the theories of staff motivation in terms of their application in practice, consider groups of motivation methods and evaluate their effectiveness. It is determined that for the efficiency of staff at the enterprise, it is necessary to approach each employee individually. The set of incentives that can (and should) be used to encourage the employee to perform their duties properly is staff motivation. This motivation begins with the selection of high-class professionals for the position and is maintained during the work of the head.

Key words: employees, motivation, services sector, methods of motivation, forms of motivation. 